\title{
Structural Analysis of the Equation Model on Store Atmosphere towards Hedonic Value and Consumer Impulsive Buying (Study at Majapahit Food Center)
}

\author{
Rini Anggriani ${ }^{1}$, Anthony Anggrawan ${ }^{2}$, Irwan Cahyadi ${ }^{3}$ \\ ${ }^{1}$ Management, Universitas Bumogora, e-mail : rinianggriani@universitasbumigora.ac.id \\ ${ }^{2}$ Computer Science, Universitas Bumigora, e-mail : anthony.anggrawan@universitasbumigora.ac.id \\ ${ }^{3}$ Management, Universitas Bumogora, e-mail : irwancahyadi@universitasbumigora.ac.id
}

Article history:

Received : 22-08-2020

Revised : 14-09-2020

Accepted : 15-09-2020

\section{Keywords:}

Structural equation

modeling;

Store atmosphere;

Hedonic value;

Impulsive buying;

Majapahit food center

\section{ABSTRACT}

This study aims to determine the analysis of Structural Equation Modeling (SEM) of store atmosphere on Hedonic Value and Impulsive Buying of Consumers at the Majapahit Food Center. This type of research uses causality research with a sample of respondents who are consumers who visited at Majapahit Food Center Mataram. The sampling technique used the accidental sampling technique. The study population was 100 visitors to the Majapahit Food Center. Sampling using the accidental sampling technique. The data collection technique used a questionnaire with a Likert scale measuring instrument. The data analysis method used is a validity test, reliability test, using SPSS, and data analysis using Structural Equation Modeling (SEM) with AMOS. The results of the study stated that the store atmosphere has a positive and significant effect on Hedonic Value and the Store Atmosphere has a positive and significant effect on Impulsive Buying and Hedonic Value has a positive and significant effect on Impulsive Buying Consumers in the Majapahit Food Center Study.

This is an open access article under the CC BY-SA license.

DOI: https://doi.org/10.30812/varian.v4i1.851

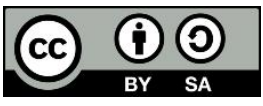

\section{A. INTRODUCTION}

Business development trends in the era of 4.0 continue to increase. This phenomenon occurs in line with the rate of population growth in Indonesia which continues to increase and consumer behavior in fulfilling needs, wants and tastes that continues to change dynamically from time to time. From BPS data in 2015 , the total population of Indonesia was recorded at 238,518,000 and it is predicted that in 2020 it will increase to $271,066,000$ people. This increase is projected to occur in various regions, one of which is NTB. This is a potential market opportunity for every business actor. Every business actor must be sensitive to any changes that occur in to survive during increasingly uncontrollable business competition, including MSMEs engaged in the food and beverage or culinary business. The MSME sector is one of the promising strategic sectors as well as supporting the community's economy, so it's no wonder that marketers take advantage of this opportunity. Various marketing strategies have been developed by business people, both internal factors, such as the store atmosphere. According to (Kotler, 2013)store atmosphere as a marketing tool. According to (Prawira \& Suparna, 2015) one of the buying behaviors that marketers want to take advantage of is impulsive buying.

Majapahit Food Center (MFC) Mataram is one of the MSMEs that has been able to withstand the tough competition to date. The business, which was founded in February 2018, is engaged in restaurant services with 17 local SME brands in it. This restaurant is the first restaurant in Mataram City that offers a self- 
service concept with tens to hundreds of variants of typical food menus from various archipelago. One of the strategies implemented by Majapahit Food Center (MFC) Mataram is one of the MSMEs that has been able to withstand the tough competition to date. The business, which was founded in February 2018, is engaged in restaurant services with 17 local SME brands in it. This restaurant is the first restaurant in Mataram City that offers a self-serve concept with tens to hundreds of variants of typical food menus from various archipelago. One of the strategies implemented by MFC to survive and exist in rapid competition and the proliferation of similar businesses is to manage the atmosphere of creative indoor and outdoor store so that it can attract consumers' attention. The indoor restaurant concept is made contemporary with a combination of trendy and modern design elements that prioritizes comfort for every visitor. Not only that, the concept of "Instagrammable" is the main attraction. Especially for the outdoor area there is lighting with open and authentic walls with wooden pillars made of natural materials, surrounded by green plants so that consumers feel comfortable. On certain days live music is held, so it's no wonder that MFC is still crowded with local and international consumers. According to (Yistiani, \& Yasa, 2012) if consumers feel comfortable with the atmosphere (atmosphere) where shopping is supported by emotional encouragement or a positive mood or (hedonic value) it will allow an increase in impulsive purchases. Meanwhile, according to (Turkyilmaz et al., 2015) a person's personality atmosphere can trigger impulsive buying.

To determine the relationship between research variables, various statistical analyzes can be used, one of which is SEM modeling. In this study, SEM analysis aims to analyze the effect of store atmosphere on hedonic value and impulsive buying among consumers who shop at MFC. SEM is a multivariate analysis that can analyze the relationship between variables in a more complex manner (Ferdinand, 2002). Although in its development the use of various statistical tools continues to be developed but is research with SEM analysis is still not much. This is in line with empirical research (Akram et al., 2016) which reveals that very few studies analyze data using SEM.

Research using SEM has been conducted by (Liu \& Song, 2020) who found that consumer pleasure and emotional arousal in shopping directly have a positive effect on impulsive buying behavior. The SEM approach is also used in research (Akram et al., 2016) to examine the effect of store atmosphere on impulsive purchases with demographic variables such as age, gender, and education level) as moderating variables. The results of SEM modeling in the first model and the last model show that store atmosphere has a significant effect on impulsive buying, but demographic factors such as gender and education have no effect on impulsive buying.

Research (Kartika \& Rofiaty, 2017) uses the Partial Least Square (PLS) path analysis, with the results showing that there is a significant influence on store atmosphere and hedonic value on impulsive purchasing decisions for consumers who shop for fashion products at modern retail. Furthermore, research (Setiawati \& Sukawati, 2017) using path analysis shows that outlet atmosphere has a positive and significant effect on the value of hedonic and impulsive purchases and there is a positive and significant influence on the hedonic value variable on impulsive purchases in consumers who shop for fashion products at modern retail. Research conducted by (Ratnasari, 2015) using path analysis found that outlet atmosphere has a positive and significant effect on hedonic and impulsive buying values and hedonic value has a positive and significant effect on impulsive purchases. However, the findings (Supriyono \& Iskandar, 2016)using multiple linear regression analysis show that the store atmosphere can affect the emergence of consumer hedonic value, but has a significant negative effect on impulsive purchases. Different results on findings (Anggriani, 2017) using SEM analysis found that hedonic motivation that triggers hedonic value does not affect impulsive buying.

Previous research has examined the store atmosphere on the hedonic value and impulsive purchases of consumers in modern retail which are identical to fashion products with various statistical analysis. However, it is still very rare to test this variable in the restaurant sector that focuses on food with analysis tools using SEM. The selection of research objects in the field of MSMEs at MFC, was first carried out. This research is one way to answer this. 


\section{B. LITERATURE REVIEW}

\section{Analysis Structural Equation Modeling (SEM)}

According to (Ferdinand, 2002) Structural Equation Modeling (SEM) is a multivariate analysis that can analyze the relationship between variables in a more complex manner. This technique allows the researcher to examine the relationship between latent and manifest variables, the relationship between one latent variable and other latent variables, and to reveal measurement errors. Meanwhile, according (Ghozali, 2008) latent variables are variables that cannot be measured directly and require several indicators as proxies, while the manifest variable is an indicator used in the measurement. SEM can estimate the relationship between variables with many relationships. This relationship is formed in a structural model (the relationship between the dependent and independent latent variables). In addition, SEM can also describe the relationship pattern between latent constructs (unobserved) and manifest variables (indicator variables).

\section{Store Atmosfere}

In (Kotler, 2013) the store atmosphere is an atmosphere that suits its target market and that can attract consumers to buy. According to (Pemayun \& Ekawati, 2016) in today's competitive business, the atmosphere of outlets is considered as one of the important things for retail stores. In (Fahd, 2015) stated there are two kinds of shopping motivations that are the seller's concern in providing an atmosphere in the appropriate outlets. The first is a utilitarian motif-oriented group that attaches more importance to the functional aspect. However, the group will at least choose well-organized, clean, and air-conditioned store. Visual appeal and additional amenities are not too important for consumers. A second group is a group that is oriented recreation, visual merchandising, and complete facilities are the deciding factors of consumer decisions in visiting an outlet. Therefore, the sellers should dress up the shopping place as attractively as possible.

\section{Hedonic Value}

According to (Yuliawati \& Suarna, 2017) hedonic value is one of the important concepts in consumer behavior that has been widely researched but until now is still interesting to explore. In general, it can be understood that the motivation for shopping there is indeed to make ends meet, but there are also just for fun looking for entertainment or recreation. Hedonistic consumption includes aspects of behavior related to multi-sensory (benefit of the entire function of the human senses), fantasy, and emotional consumption controlled by benefits such as pleasure in using aesthetic products and approaches.

\section{Impulsive Buying}

Impulsive buying behavior is behavior that buys goods/services spontaneously or unplanned in advance (Made \& Purnama, 2019). The same study revealed that shopping can change a person's mood, relieve stress, or relieve boredom. Most shopping creates unplanned purchasing behavior or impulsive buying behavior. According to (Minor, 2012) impulsive buying is a buying action that was not previously recognized consciously as a result of consideration or intention to buy formed before entering the store.

\section{The Relationships Between Variables}

An empirical study conducted by (Kartika \& Rofiaty, 2017) found that there was a significant influence on the store atmosphere and hedonic value on consumer impulse buying decisions. Research (Akram et al., 2016) with structural equation modeling (SEM) analysis found that the atmosphere has a significant effect on impulsive buying. Research (Setiawati \& Sukawati, 2017) found that the store atmosphere has a positive and significant effect on the hedonic value and impulsive buying and there is a positive and significant influence of hedonic value variables on impulsive buying.

Impulsive buying is categorized as hedonistic purchasing behavior (Chang et al., 2011), (Ratnasari, 2015) the store atmosphere has a positive and significant effect on the hedonic value and impulsive buying and hedonic value has a positive and significant effect on impulsive buying. Previous research conducted by (Supriyono \& Iskandar, 2016) found that the store atmosphere had a significant positive 
effect on the formation of hedonic consumer value but had a significant negative effect on impulsive buying. Hedonists are one of the factors that can influence impulsive buying behavior (Made \& Purnama, 2019) in the same study revealing that shopping can change a person's mood, relieve stress, or relieve boredom. (Turkyilmaz et al., 2015) found that a person's personality mood can trigger impulsive buying. Based on the description can be submitted the research hypothesis as follows;

$\mathrm{H} 1 \rightarrow$ There is an effect of store atmosphere on the hedonic value of consumers who shop at MFC.

$\mathrm{H} 2 \rightarrow$ There is an effect of store atmosphere on impulsive buying of consumers who shop at MFC.

$\mathrm{H} 3 \rightarrow$ There is an effect of hedonic value on impulsive buying of consumers who shop at MFC.

\section{RESEARCH METHOD}

This type of research uses causality research with a sample of respondents is consumers who shop at Majapahit Food Center Mataram (MFC). Sampling techniques using accidental sampling techniques. The data collection tool uses a scale questionnaire Likert point 1-5 (Strongly Disagree to Strongly Agree). The data source uses primary data through the dissemination of questionnaires. Data analysis techniques using Structural Equation Modeling (SEM). The study used 3 variables with 14 indicator items. According to (Ferdinand, 2002) The number of indicators multiplied by 5-10 so that based on these criteria the number of research samples as much as $14 \times 7=98$ in this study took to 100 respondents. According to (Ghozali, 2008) the size of the sample size has an important role in the interpretation of Structural Equation Modeling (SEM) results and recommends that sample sizes between 100-200 be used for maximum-likelihood estimates depending on the parameters estimated. Here's the data processing flow with structural equation modeling (SEM) namely as;

1. Determination of variables and research indicators (Table 1)

2. Discussion and Results
a. Testing the validity of research intrusion with SPSS and CFA test with SEM.
b. Instrument reliability testing using Cronbach alpha, composite reliability, and AVE coefficients.
c. Statistical description.
d. Structural Equation Modeling (SEM).

At the end of the analysis, the suitability of the model is estimated using several model conformity indexes such as; Chi-square Relative (CMIN/DF), Goodness-of-Fit Index (GFI), Adjusted Goodness-ofFit Index (AGFI), Comparative Fit Index (CFI), and Root Mean Square Error of Approximation (RMSEA), TLI (Tucker Lewis Index), IFI (Incremental Fit Index), NFI (Normed Fit Index) ( Ferdinand, 2014) and (Wijanto, 2008).

3. The results of hypothetical tests to determine the influence between endogenous latent variable store atmosphere $(\mathrm{X})$ and hedonic value $\left(\mathrm{Y}_{1}\right)$ on exogenous latent variable impulsive buying $\left(\mathrm{Y}_{2}\right)$.

Conclusion and sugestion

\section{RESULTS AND DISCUSSION}

\section{Validity Test}

To find out which research instrument or measuring instrument is used, a validity test and a test of the reality of the instrument are carried out. This validity test is done to find out if all statements in the research instrument submitted to measure research variables are questions or statements that should be asked. Validity tests relate to the accuracy or accuracy of research measuring instruments. Testing of instrument validity was conducted using Pearson's correlation coefficient with SPPS and testing conducted resulted in a significant correlation coefficient with sig levels above $5 \%$, so it can be concluded that the details of the research instrument are valid.

The second validity test in this study used a convergent validity test using Confirmatory Factor Analysis (CFA). CFA includes measurement models that describe the relationship between the variables studied and concepts or latent variables. The value of convergent validity can be seen from the Loading Factor of each variable studied. The lambda $(\lambda)$ value or loading factor is greater than 0.40 , if it is less 
than 0.40 then the model needs to be revised by issuing an ineligible variable indicator (Ferdinand, 2014). The next table of $3 \mathrm{~d}$ reliability test instruments using the Cronbach Alpha coefficient, with a minimum internal consistency coefficient of 0.60 (Taherdoost, 2016),here are the results of the test validity of the study.

Table 1. Person Correlation test Results and Loading Factor with CFA

\begin{tabular}{clcccc}
\hline \multirow{2}{*}{ Variables } & \multicolumn{1}{c}{ Indicator } & $\begin{array}{c}\text { Pearson } \\
\text { Correlatio } \\
\text { n (SPSS) }\end{array}$ & $\begin{array}{c}\text { Factor } \\
\text { Loding }(\lambda) \\
\text { (CFA-SEM) }\end{array}$ & $\begin{array}{c}\text { Item } \\
\text { Numb } \\
\text { er }\end{array}$ & Ket \\
& Interior design (x1) & 0,88 & 0,84 & 1 & Valid \\
Atmosfer & Layout (x2) & 0,81 & 0,75 & 2 & Valid \\
Gerai & Exposure (x3) & 0,86 & 0,88 & 3 & Valid \\
(X) & Color (x4) & 0,90 & 0,89 & 4 & Valid \\
& Music (x5) & 0,89 & 0,87 & 5 & Valid \\
& Following trend (y1.1) & 0,81 & 0,79 & 6 & Valid \\
Hedonic & Desire to coddle (y1.2) & 0,80 & 0,69 & 7 & Valid \\
Value & Shopping for getting fun (y1.3) & 0,85 & 0,82 & 8 & Valid \\
(Y1) & Excessive desire (y1.4) & 0,76 & 0,75 & 9 & Valid \\
& Interaction shopping (y1.5) & 0,84 & 0,78 & 10 & Valid \\
Impulsive & Spontaneous purchase (y2.1) & 0,85 & 0,81 & 11 & Valid \\
Buying & extravagant (y2.2) & 0,87 & 0,82 & 12 & Valid \\
(Y2) & Hasty purchase (y2.3) & 0,88 & 0,84 & 13 & Valid \\
& Purchase affected emotions (y2.4) & 0,88 & 0,84 & 14 & Valid \\
\hline
\end{tabular}

(source; data primer diolah)

Validity test results with person correlation and CFA show all research instrument items for all question items in variables are valid items because they have a correlation value with sig $\geq 0.50$ or above $5 \%$ levels.

\section{Reliability Test}

Reliability tests are related to measurements evidenced by testing consistency and stability. The reliability test is defined as the level at which measurements are used free of random errors and have consistent results (Zikmund, 2003). Reliability tests in this study can be seen based on CA, CR, and AVE values.

The reliability test in this study looked at CA values that showed how well question items correlated positively with each other the acceptable CA value was 0.6 or more (Zikmund, 2003). Another study emphasized that a minimum Alpha $(\alpha)$ value of 0.7 is more desirable. Next look at the CR value. According to (Hair Jr et al., 2010) the acceptable level of reality is $\geq 0.70$. Next look at the AVE value, which indicates the number of variances of the indicators extracted by the latent construct developed. The high AVE value indicates that these indicators have represented well the latent construct developed (Hair Jr et al., 2010) in (Ferdinand, 2014). The minimum AVE value to a state that reliability has been achieved is 0.50 (Wijanto, 2008) and (Latan, 2013) following the test of research reality.

Table 2. CA , $C R$ and $A V E$ value per Variable

\begin{tabular}{ccccc}
\hline Variable & CA & $\boldsymbol{C R}$ & $\boldsymbol{A V E}$ & Ket \\
\hline Store atmosphere $(\mathrm{X})$ & 0,888 & 0,93 & 0,85 & Reliabel \\
Hedonic Value $\left(\mathrm{Y}_{1}\right)$ & 0,864 & 0,88 & 0.77 & Reliabel \\
Impulsive Buying $\left(\mathrm{Y}_{2}\right)$ & 0,844 & 0,90 & 0.83 & Reliabel \\
\hline Note; CA (Crombach's Alpha), CR (Composite Reliabilitas), AVE (Average Variance Extracted).
\end{tabular}

Based on Table 2 data processing results obtained to three variables already have a CA value (Cronbach's Alpha) $\geq 0.6$, CR (Composite Reliability) $\geq 0.70$, and AVE (Average Variance Extracted) $\geq 0.5$. So it can be said that all the constructs in this study meet the reliability test so that it can be said reliable. 


\section{Descriptive Statistics}

Descriptive statistics are performed to group the characteristics of respondents based on the gender, age, education level, and work of the study respondents. The following are characteristics of respondents who were processed using SPPS as a result of the dissemination of questionnaires that have been shared with 100 consumers who shop for food in MFC. The results of the dissemination questionnaire obtained data characteristics of respondents based on gender, age, education level, and occupation. Here is an overview of the characteristics of respondents research.

Based on Table 3. it can be found that the majority of respondents are female, namely 63 people or 63 percent, and male respondents as many as 37 people or 37 percent. This is because usually women prefer shopping and tend to have more free time shopping than men. For characteristics of respondents based on age in Table 3 shows the majority of respondents aged 20-30 years old as much as 53 people or by $53 \%$, respondents aged 31-40 years old by 24 people or by $24 \%$, respondents aged $41-50$ years old by 18 people or by $18 \%$ and respondents aged 50 years as many as 5 people or by $5 \%$. This indicates that the dominant MFC visitors are 20-30 years old who are nota bene are teenagers or young students who like to shop for culinary. Because of the characterization of education level, the majority of respondents are mostly educated in S1 as many as 61 people or by $61 \%$. This corresponds to the employment rate of respondents, the majority of whom are young students. Based on Table 3 shows that the characteristics of respondents based on work are more dominated as students as 38 people or by 38\%, this shows MFC visitors are mostly from the millennials youth of foodies while looking for a cool and modern gathering place. Another factor is the location of the restaurant which is strategically surrounded by the campus complex and student area.

Table 3. Categories of Respondents

\begin{tabular}{cccc}
\hline The Character & Male & $\begin{array}{c}\text { Respondents } \\
\text { (Persons) }\end{array}$ & Presentage \\
\hline \multirow{3}{*}{ Gender } & woman & 37 & $37,00 \%$ \\
& Total & 63 & $63,00 \%$ \\
\hline \multirow{4}{*}{ Age } & $20-30$ years & $\mathbf{1 0 0}$ & $\mathbf{1 0 0 \%}$ \\
\cline { 2 - 4 } & $31-40$ years & 53 & $53,00 \%$ \\
& $41-50$ years & 24 & $24,00 \%$ \\
& $>50$ years & 18 & $18.00 \%$ \\
& Total & 5 & $5,00 \%$ \\
\hline \multirow{4}{*}{ Education } & High School Education & 12 & $3,08 \%$ \\
& D3 & 18 & $3,08 \%$ \\
& S1 & 61 & $29,23 \%$ \\
& S2 & 9 & $23,08 \%$ \\
\hline \multirow{4}{*}{ Accupation } & Total & 100 & $18,00 \%$ \\
& Civil Servant & 38 & $38,00 \%$ \\
& Students & 32 & $32,00 \%$ \\
& Private $/$ entrepenurship & 12 & $12,00 \%$ \\
\cline { 2 - 4 } & Other & $\mathbf{1 0 0}$ & $\mathbf{1 0 0} \%$ \\
\cline { 2 - 4 } & Total & & \\
\hline
\end{tabular}

(sumber; primary data)

\section{Structural Equation Modeling (SEM)}

\subsection{Goodness-Of-Fit (GOF) Test}

The results of the Goodness-Of-Fit (GOF) Test with cut-of-value criteria seen from the smaller chisquare value are better when $\leq 2.00$. RMSEA (root mean square error of approximation) $<0.08$, GFI (goodness-of-fit) GFI value $\geq 0.9$ is a good fit, while $0.8 \leq$ GFI $\geq 0.9$ is referred to as marginal fit or acceptable model, AGFI (adjusted goodness of fit index) with a value of 0.9 (AGFI $\geq 0.9$ ) is said to be fit, marginal when it has AGFI, $0.8 \leq \mathrm{AGFI} \leq 0.9$ ), the expected CMIN/DF is less than or equal to 2.00, TLI (tucker lewis index) TLI value ranges from 0 to 1 . TLI value $\geq 0.9$ is a good fit while TLI value, $0.8 \leq$ TLI $\leq$ 
0.9 is said to be a marginal fit, and CFI (comparative fit index) model is said to be a good fit if the CFI value is greater or equal to $0.9(\mathrm{CFI} \geq 0.9$ ) and is said to be marginal fit when the CFI value, $0.8 \leq \mathrm{CFI} \leq 0.9$, IFI (incremental fit index) $\geq 0.90$, NFI (normed fit index) $\geq 0,90$ (Ferdinand, 2014), (Wijanto, 2008).

Table 4. Overall Model Feasibility Test Results

\begin{tabular}{cccc}
\hline GOF & Cut-off-value & Result & Conclusions \\
\hline$\chi^{2}$ (Chi-square) & $\leq 2.00$ & 1,610 & Good fit \\
RMSEA & $\leq 0,08$ & 0,078 & Good fit \\
GFI & $\geq 0,90$ & 0,853 & Marginal fit (acceptable) \\
AGFI & $\geq 0,90$ & 0,792 & Marginal fit (acceptable) \\
TLI & $\geq 0,90$ & 0,947 & Good fit \\
CFI & $\geq 0,90$ & 0,957 & Good fit \\
IFI & $\geq 0,90$ & 0,958 & Good fit \\
NFI & $\geq 0,90$ & 0,896 & Marginal fit (acceptable) \\
\hline
\end{tabular}

(source; primary data processed)

From Table 4 above obtained the results that based on the feasibility testing of the model shows the values of 2,00 (Chi-square), RMSEA, TLI, CF, and IFI with conclusions can be said to be Good fit, while GFI, AGFI, and NFI values with marginal fit (acceptable) conclusions or have met GOF criteria or meet the specified cut-of-value requirements (Wijanto, 2008). So it can be concluded that the constructs used in this study already reflect endogenous latent variables (store atmosphere) as well as exogenous latent variables (hedonic value and impulsive buying) that are analyzed along with each indicator. Here's a picture of the overall SEM model.

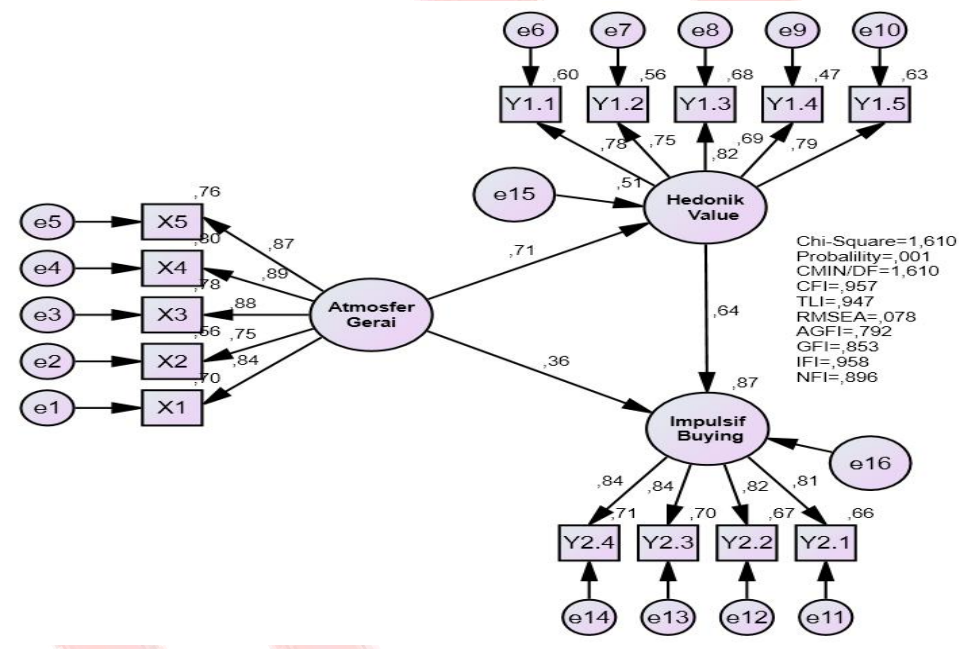

Figure 1. Full Model SEM

\subsection{Hypothesis Test Results}

In general, this hypothesis test is done by looking at the critical ratio value and the significant value of $\mathrm{p}$ as a result of data processing compared to the required statistical constraints. The required critical ratio is $\geq 1.96$ and the required probability value is below 0.05 . If the results of data processing meet these requirements, then the hypothesis in the proposed research is declared acceptable. Each hypothesis test in this study will be discussed in Table 5 based on the output results of the analysis of the path performed, it can be known the significance of the influence and the critical ratio value which is the tvalue value. These results are used for testing the following research hypothesis. 
Table 5. Full Model Structural Equation Modeling (SEM) Results

\begin{tabular}{clccccc}
\hline $\begin{array}{c}\text { Hypothesi } \\
\text { s }\end{array}$ & \multicolumn{1}{c}{ Path } & $\boldsymbol{\beta}$ & t-value & $\boldsymbol{P}$ & Label & $\begin{array}{c}\text { Conclusio } \\
\text { n }\end{array}$ \\
\hline H1 & $\begin{array}{l}\text { Store atmosfer } \rightarrow \\
\text { Hedonic value }\end{array}$ & 0,71 & 6,422 & $* * *$ & Sig. & Support \\
\hline H2 & $\begin{array}{l}\text { Store atmosfer } \rightarrow \\
\text { impulsive buying }\end{array}$ & 0,36 & 3,744 & $* * *$ & Sig. & Support \\
\hline H3 & $\begin{array}{l}\text { Hedonic value } \rightarrow \\
\text { impulsive buying }\end{array}$ & 0,64 & 5,520 & $* * *$ & Sig. & Support \\
\hline
\end{tabular}

Keterangan ${ }^{* * *}$ ) tingkat Sig $<0,001$

\subsubsection{Influence of store atmosphere on Hedonic Value}

Based on the results of data processing with SEM modeling it is known that the critical ratio value for the influence between the outlet atmospheric variables against the hedonic value as seen in Table 5 is 6,422 with a sig level of $<0.001\left(^{* * *}\right)$. Both values show qualified results, namely $\geq 1.96$ for critical ratio and $P<0.05$. While the coefficient value of the path $(\beta)$ is 0.71 . This indicates that the atmosphere of the outlet has a positive contribution as well as the influence of hedonic value. This means that if the more attractive the atmosphere of outlets on MFC then it can trigger higher hedonic value consumers to shop at MFC. So it can be concluded that hypothesis 1 in this study can be supported or accepted.

MFC's strategy of managing the atmosphere of outlets is made comfortable so it can trigger the mood and positive emotions of consumers in the end providing a memorable shopping experience as well as entertainment. These findings support the theory that (Kotler, 2013) marketers deliberately create a fun atmosphere in stores aimed at attracting consumers who want to shop at once for fun. The results of the study supported the research (Supriyono \& Iskandar, 2016). The atmosphere of the outlet can trigger pleasure and mood (Davis et al., 2008), (Ratnasari, 2015) that the atmosphere of the outlet has a positive and significant effect on hedonic value. (Bhatt, 2020) the environmental atmosphere impacts the consumer experience holistically.

\subsubsection{Influence Of Store Atmosphere on Impulsive Buying}

Based on the hypothetical test results seen in Table 5 obtained sig levels of $<0.001\left(^{* * *}\right)$ at $\mathrm{P}<0.05$ and coefficient pathways $(\beta)$ of 0.36 , the critical ratio or t-count value of 3,744 are greater than the t-table value of $\geq 1.96$ which means that if the more attractive the store atmosphere will increase the impulsive buying that consumers who shop at MFC, this suggests that there is a positive and significant influence between the store atmosphere on impulse buying MFC consumers, so hypothesis 2 in this study can be supported or accepted.

Related to this, MFC has managed to increase consumer comfort in line with the theory (Kotler, 2013) that says that store atmosphere as a marketing tool. The atmosphere of convenient, attractive outlets is very effective in generating a positive mood of consumers in this regard to shopping as pleasure and entertainment that ultimately encourages consumers to go through unplanned purchases or impulsive buying. While the findings (Bhatt, 2020) reveal consumer emotional arousal is part of the hedonic value of consumers that ultimately triggers impulsive buying. The results of this study support empirical findings by (Ratnasari, 2015) that the store atmosphere has a positive and significant effect on impulsive buying.

\subsubsection{Influence of Hedonic Value on Impulsive Buying}

Based on the hypothetical test results seen in Table 5 shows with a sig level of $<0.001$ (***) less than 0.05 with a positive beta quality $(\beta)$ of 0.64 with a critical ratio or t-count of 5,520 greater than the $t$ table value of $\geq 1.96$ which means that if the hedonic value of the consumer is higher, then the higher the impulsive buying of consumers who shop at MFC. Thus the third hypothesis that states there is a positive and significant influence between hedonic value to impulsive buying is acceptable. Thus hypothesis 3 in this study can be supported or accepted. 
The majority of current consumers are likely to buy what is going viral at the time, no exception to food or culinary products. This indication that shopping no longer places a utilitarian value but rather to meet hedonic value. Hedonic shopping behavior where consumer tends to shop for pampering and follow trends as a trial and error event even if not much needed. According to (Made \& Purnama, 2019) hedonistic value in a person is one of the factors that can influence impulsive purchasing behavior. The results of this study are in line with (Chang et al., 2011) impulsive buying categorized as hedonistic purchasing behavior. the results of this study support the findings (Ratnasari, 2015). The results of this study are different from the findings (Anggriani, 2017) where hedonic motivation does not affect impulsive buying purchases. Although the hedonic motivation of consumers as a hedonic trigger is high value but does not necessarily increase impulse buying. This is a reasonable thing, according to (Anggriani, 2017) someone who has a high hedonic value sometimes has a lot of consideration when going to make a purchase such as one of them is the consideration of economic factors.

\section{E. CONCLUSION AND SUGGESTION}

The results of the analysis using Structural Equation Modeling (SEM) show that store atmosphere has a positive and significant effect on hedonic value. This means that the more attractive the outlet atmosphere is, the higher the hedonic value of consumers to forget about MFC. And, Store atmosphere has a positive and significant effect on impulsive buying. this means that if the store atmosphere is more attractive, the more impulsive purchases made by consumers made at MFC will be higher. Then, Hedonic value has a positive and significant effect on impulsive buying. This means that the higher the hedonic value, the higher the implementation of impulsive purchases made by consumers at MFC.

The suggestions that can be recommended in this study are; 1) Making the shop atmosphere at MFC more attractive so that it can continue to increase consumer enjoyment while shopping. 2) Continue to improve promotional strategies that can make consumers interested in shopping at MFC, given the continued proliferation of similar businesses.

This research was only conducted on MFC with the type of product is food. It should be followed up in researching at different locations with larger amounts of sample. Besides, it is hoped that researchers can further develop this study by adding other variables so that more diverse research results can be obtained and can be compared for example by comparing the hedonic value with consumer utilitarian value where motive consumer consumption can not be released from the two values. In the future, this research can provide practical implications that contribute to interested parties, in this case, is MFC marketers to continuously improve marketing strategies especially in promoting consumer spending behaviour

\section{ACKNOWLEDGEMENTS}

Researchers would like to thank the Universitas Bumigora for giving permission to collaborate in the field of research and provide moral support, so that this research can be carried out well.

\section{REFERENCES}

Akram, U., Hui, P., Khan, M. K., \& Hashim, M. (2016). Impact of Store Atmosphere on Impulse Buying Behaviour: Moderating Effect of Demographic Variables. 9(7), 43-60.

Anggriani, R. (2017). Influence of Materialism, Hedonic Motivation On Impulsive Buying, and Tendency to Compulsive Buying Online Among Mataram University Students. JMM -Unram - Master of Management Journal, 6(2), 1-20.

Bhatt, G. (2020). Attractive and Facilitating Store Atmospheric Stimuli Validating The Scales. 48(4), 363-379.

Chang, H., Eckman, Molly., \& Yan, R.-N. (2011). The International Review of Retail , Distribution and Consumer Research Application of the Stimulus-Organism- Response model to the retail environment : the role of hedonic motivation in impulse buying behavior. The International Review of Retail, Distribution and Consumer Research, 21(3), 37-41.

Davis, L., Wang, S., \& Lindridge, A. (2008). Culture Influences On Emotional Responses To On-Line Store Atmospheric Cues. 61(8), 806-812.

Fahd, F. (2015). Analysis of The Influence of Promotion And Atmosphere of Outlets On Impulse Buying Through Positive Emotions As Intervening Variables.

Ferdinand, A. (2002). In Structural Equation Modeling In Management Research (2nd ed.). Bp Undip.

Ferdinand, A. T. (2014). Management Research Method (5th ed.). Bp Undip. 
Ghozali, I. (2008). Aplikasi Analisis Multivariate Dengan Program SPSS” (4 (ed.)). Universitas Diponegoro.

Hair Jr, J. F., Black, W. C., Babin, B. J., \& Anderson, R. E. (2010). Multivariate Data Analysis Seventh Edition. Pearson Prentice Hall.

Kartika \& Rofiaty, R. (2017). The Influence of Hedonic Shopping value and Atmosphere of Outlets On Impulsive Purchasing Decisions With Mediated Impulsive Reactions. Journal of Business And Management, 4(2), $188-197$.

Kotler, P. (2013). Marketing Principles (12th ed.). Erlangga.

Latan, H. (2013). Structural Equation Model, Theory and Implementation of AMOS 21. Penerbit AlfaBeta.

Liu, B., \& Song, M. (2020). Stimulus Organism Response Model Based Analysis On Consumers OnlineImpulse Buying Behavior.

Made, D., \& Purnama, F. (2019). Hedonic Shopping Motivation, Shopping Lifestyle, Price Reduction toward Impulse Buying Behavior in Shopping Center. 3(1), 48-54.

Minor, M. J. . \&. (2012). Consumer Behavior (Erlangga (ed.).

Pemayun, T., \& Ekawati, N. (2016). The Influence of Promotion, Atmosphere of Outlets, And Merchandise On Impulsive Purchase on Hardy's Mall Gatsu Denpasar. 1st, 5(7), 244242.

Prawira Laksana, K., \& Suparna, G. (2015). The Role Of Hedonist Motivation Mediates The Influence Of Materialism On Impulsive Purchasing Behavior Online. EE-Journal of Management University of Udayana, 4(6), 254896.

Ratnasari, V. A. (2015). The Influence of Store Atmosphere On Hedonic Shopping Value And Impulse Buying (Survey On Consumers Hypermart Malang Town Square). Journal of Business Administration (JAB), 1(1).

Setiawati \& Sukawati. (2017). The Effects of Merchandise and Store Atmosfere Toward Hedonic Value and Impulsive Buying Behavior at Lippo Mall Kuta. Unud, E-Jurnal Management, 6(9), 5205-5231.

Supriyono \& Iskandar. (2016). Influence of Store Atmosphere and Service on Hedonic Value and Unplanned Purchase of Indomaret Surakarta Customers. Aktual, 2(1), 43-59.

Taherdoost, H. (2016). Validity and Reliability of the Research Instrument: How to Test the Validation of a Questionnaire/ Survey in a Research. International Journal of Academic Research in Management, 5(3), 28-36.

Turkyilmaz, C. A., Erdem, S., \& Uslu, A. (2015). The Effects of Personality Traits and Website Quality on Online Impulse Buying. Procedia - Social and Behavioral Sciences, 175, 98-105.

Wijanto, S. H. (2008). Structure Equation Modeling dengan Lisrel. 8.8. Graha Ilmu.

Yistiani, \& Yasa, I. G. (2012). The Influence of Atmospheric Outlets and Retail Services on Hedonic Value and Impulsive Purchase of Solar Customers of Duta plaza Department Store in Denpasar. Journal of Business Management, Business Strategy, and Entrepreneurship, 6 (2), 139-149.

Yuliawati, Y., \& Suarna, I. F. (2017). Hedonics Shopping at Student. Ekobis, 1, 41-52.

Zikmund, W. . (2003). Bussiness Research Metdhods" (Edition, 7). United States of America. 